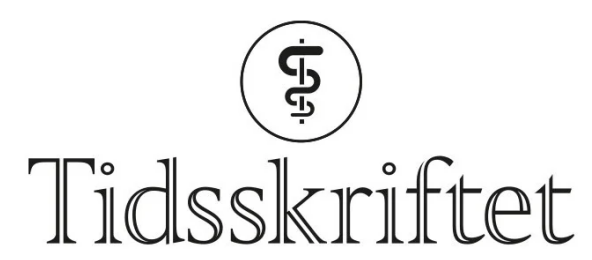

DEN NORSKE LEGEFORENING

\title{
Arnt Edvin Andersen
}

\author{
MINNEORD
}

JOSTEIN GLEDITSCH

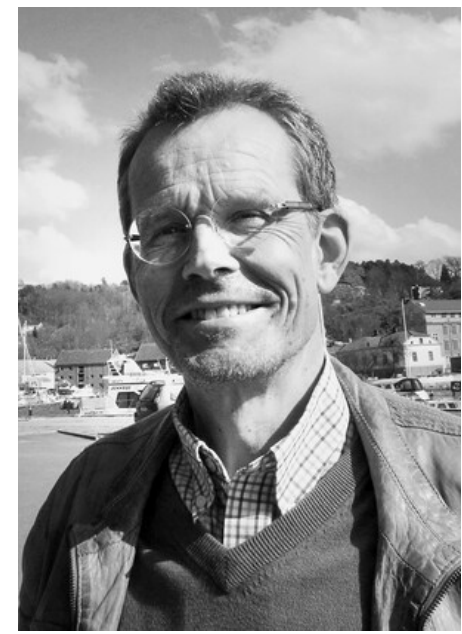

Vår gode venn og kollega Arnt Edvin Andersen sovnet 22. august stille inn, 64 år gammel, etter et langt sykeleie. Akutt hjertestans og påfølgende gjenopplivning i mai 2018 endret tilværelsen hans til et liv på institusjon, etter at rehabilitering til tidligere funksjonsnivå viste seg umulig.

Arnt Edvin Andersen viste tidlig et meget stort talent som idrettsutøver. Han ble tre ganger norgesmester i juniorklassen i orientering og ble høyt plassert på nasjonalt nivå i langrenn. Under studietiden i Freiburg ble han tysk studentmester i langrenn og feiret triumfer i terrengløp.

Etter fullført studium og turnus jobbet han i Arvika i Sverige. Fra 1987 var han ansatt som assistentlege ved radiologisk avdeling på Sarpsborg sykehus, og etter tjeneste ved Ullevål sykehus ble han overlege på Sentralsykehuset i Fredrikstad med barneradiologi som spesialområde. I 1998 overtok han som avdelingsoverlege i en alder av 41 år.

Som avdelingsoverlege var han pådriver for innføring av digital bildelagring. Han så klart radiologiens $\varnothing$ kte betydning i akuttdiagnostikken og satte bildediagnostikk på dagsordenen i sykehuset. Som optimist evnet han å se løsninger der andre så problemer. Da nytt $\emptyset$ stfoldsykehus skulle utformes, var det helt naturlig at Arnt var blant dem som ble spurt om råd. 
Ved siden av sykehusjobben etablerte han privat virksomhet med ultralyddiagnostikk i hjembyen Halden. I takt med at denne praksisen vokste, gikk han over i redusert stilling i sykehuset.

Arnt spilte alle rundt seg gode. Han hadde en egen evne til å formidle kunnskap og påvirke alle i virksomheten med sine gode holdninger. Der andre kunne være kritiske, kom det som oftest ros fra Arnt. På denne måten ble han et forbilde. Gjennom kunnskap, fremtidsoptimisme, gode holdninger og et ukuelig godt humør hadde han avgjørende betydning for utviklingen i avdelingen.

Etter etablering av familie og jobb fikk Arnt tid til å fortsette idrettsaktiviteten. Han brukte sin innsikt og erfaring til gode for barn og ungdom og i mange tillitsverv i Halden Skiklubb. Også her kom hans positive holdning og evne til å finne gode løsninger til nytte. Helt frem til sykdommen rammet, deltok han som en av de beste i sin klasse i langløp på ski.

Den sprekeste blant oss ble så altfor tidlig rammet av invalidiserende sykdom og er nå gått bort. Sammen med hans familie, kona Marianne og døtrene Hedvig, Ulrikke og Martine, bærer vi Arnts gode minne med oss videre.

Publisert: 25. oktober 2021. Tidsskr Nor Legeforen. DOI: 10.4045/tidsskr.21.0682

(C) Tidsskrift for Den norske legeforening 2023. Lastet ned fra tidsskriftet.no 26. april 2023. 